\title{
Develop Pre-service Continuing Education Vigorously so as to Promote the College Graduates Employment
}

\author{
Chen Weiyu, Wang Hehuan \\ BeiJing WuZi University, BeiJing, China
}

\begin{abstract}
College graduates who are valued human resources are the group full of vitality. It is hard for college graduates to find jobs because of many reasons together, but in traditional training mod, the quality structure of college graduates was hardly adapted to social and economic development of professional competence requirements for college students, highlighting the ills of the education system over the years. However, pre-service continuing education between university and company can promote the ability of college students to find jobs, which can effectively improve the employment rate. The problem to find jobs for college students is not just the questions of college graduates themselves, but also the social problem that needs to be solved for our society.
\end{abstract}

KEYWORDS: Pre-service Continuing Education; College Graduates; Employment Rate

As the demand side, enterprise and public institution couldn't afford to supply the sufficient employment for college graduates for many reasons, such as global competition, sluggish economy, adjustments of industrial structure and economic downturn of part of industry. While in recent years, the college expansion plan has made the increasing number of college graduates and college talent market in a serious oversupply. This case affects not only the social comment on education, but also the stability and harmony of our society.

\section{DEEPER CAUSES OF DIFFICULT EMPLOYMENT TO COLLEGE GRADUATES}

Data that ministry of education published shows, the number of graduates in regular college reached up to 6.89 million in 2013. In 2014, the number reached up 7.27 million, which would refresh the record. This would make 2014 year become the more difficulty year in employment. What's worse, some graduates of previous even became "Ant Family" and their living environment made people worried. The research on college student employment not only considered the employment rate of graduates, but also the employment quality of graduates. Graduates' Employment, the difficulty in where?

\subsection{Time Difference on Employment of College Graduates [1]}

Based on the experts' research, employment rate was low after graduation recently, while it would increase after half a year. Research universities' graduate employment rate was $88 \%$, while which would reach up to $94 \%$ after half a year for 985 or 211 universities. Universities that are not research universities' graduate employment rate was 59\%, while which would reach up to $90 \%$ after half a year for those universities that are not 985 or 211 universities. Higher vocational and specialized colleges' graduate employment rate was $43 \%$ and $84 \%$ [2] half a year later, which meant a proportion of graduates would find their job after half a year. But why the time finding the job would be half a year later? What was the real meaning of the half year to college graduates? In reality, companies needed college graduates to work for themselves, however, why they didn't want the college students who were recently graduated?

\subsection{Major Problem on Employment of College Graduates}

It is not difficult to find that the majors that had the highest employment rate are majors which are very professional, such as construction, medical industry, transportation, CPA and so on. For some majors, companies urgently needed employees but couldn't find any one such as mold design and 
manufacturing, psychology, mechatronics technology, car shaping technology and so on. The reason was the high demand on college students or the ability of practice that college graduates were short of?

\subsection{Level Gap on Employment of College Graduates}

Before the expansion of university enrolment, the gross enrolment rate of high school graduates was $40 \%$ more or less in 1998, however, the gross enrolment rate was $85 \%$ in 2006 after the expansion of university enrolment, which indirectly leaded skilled specialized colleges to reduce even close. In recently years, "lighting degree and lifting capacity" has become the consensus of companies. It was usual to see that some companies employed vocational high school students other than college graduates. Gray collar workers were lacked, while white-collar class was overcrowd, which leaded to Chinese imbalance in employment. Was diploma depreciated or companies just need gray collar workers other than white-collar class?

Although many reasons together lead to the situation that it is hard for college graduates to find jobs, the answer to these three problems is the same. For the development of social economy, companies have the clear demands on Professionalism of college graduates; however, in traditional training mode the quality structure of college graduates is hardly adapted to the new requirements of social development.

\section{PROBLEM OF TALENT CULTIVATION IN OUR COUNTRY COLLEGES}

The cultivation of talent is concerned to the rise and fall of the nation and the destiny of our country. What are the exactly objective problems about talent cultivation mode in our country in past or present?

In terms of enrolment scale, many universities didn't establish the professional team which analyzed the employment situation and companies' real demands. What they do was just enrolling colleges blindly for the enrolment scale, which finally leaded that the number of college graduates has been increasing. For the enrolment scale, universities set popular majors to appeal to high school graduates, however, when in their graduation which became into a serious surplus of professional talents in employment difficult.

In terms of curriculum system settings, system settings college curriculum determined the structure of knowledge and expertise, and ultimately affected the employability and competitiveness of college students. In recent years, the demand structure of China's talent market has undergone dramatic changes, but the mainstream of university professional settings still preformed traditional model, which had no change with the needs of the market, many theories of college curriculum system were too strong and practical operation was insufficient. Although the college had a strong ability to accept new knowledge, but they learnt in school during the theoretical knowledge and practical work seriously out of line, knowledge Reserve University during the work couldn't fully meet the needs. After graduating from college, university students on the one hand existed in a narrow range of knowledge, hands-on ability, skills and weak, weakening employment capacity, resulting in a difficult employment, while on the other hand is that many employers were not able to hire the right talent.

In training mode, the universities tended to focus only on-campus practice teaching in classroom activities and neglect. Admittedly, the learning process of college students from high school to college, from "this door" to "He is the door," resulted in no chance to reach the community to understand reality. Subsisting years of indoctrination education, to focus only on classroom teaching practice and neglect, leading to social adaptation of graduates, the practice did not match the ability to work with social needs. The biggest deficiency in the ability of college students was the presence of production practices and the lack of expertise knowledge. Students experienced the transition from school to the community in the process of a huge challenge, how to help students complete as soon as possible from the "campus" to "social" role change? How would they learn professional knowledge into capacity themselves? This was not only prudent for each college that must face the problem, but educators needed deep reflection.

\section{EFFECTIVE WAY TO ENHANCE THE EMPLOYABILITY OF COLLEGE GRADUATES: PRE-SERVICE PROFESSIONAL CONTINUING EDUCATION}

Rapid development in technology today, the emerge of new equipment, new technology, new technology innovation, and the understanding between jobs tactics are closely linked with the pre-service training. In the employment situation of recent years, the college graduates is still a major force in the enterprise, how to make the college graduates as soon as possible familiar with the work environment, to grasp business knowledge? How to make the college graduates accepted pre-service graduates continuing professional education in order to compensate for the lack of learning in school? There are linked between Universities and business and it is currently expediency to arrange for graduates 
short-term pre-service vocational education. The pre-service vocational education is beyond the academic full-time education, which can effectively shorten the talent gap between output and demand, led by college graduates to achieve an "outsider" to "business people" change.

From the perspective of a business, vocational continuing education training for the college graduates is carried out to establish their own corporate image, enhance their sense of belonging, and explore the potential of employees in the process, allowing graduates to familiarize themselves with the business environment and adapting to the corporate culture, transferring from "knowledge quasi talent "to" produce practical personnel ", which not only creates benefits for enterprise as soon as possible, but also builds loyalty for the company and reduce wastage.

From the student's perspective, when we go into the workplace early, we mostly need to understand the production as soon as possible, enter into the corporate culture, and prepare for the job role. By vocational continuing education, college graduates need to get corporate identity, adjust attitude, and establish the correct professional attitude and professionalism as soon as possible, with a positive attitude into new groups to lay a solid foundation for future career development.

From the perspective of university education reform, in the course of college education and teaching over the years, most colleges has been lost in the simple theory indoctrination, at the expense of students' vocational skills training. The continuing education college has relationships with market demand extremely close, so they can flexibly train specialized personnel for the enterprise in the "Order" way according to the actual needs of the employer enterprises. The new training model can not only improve the professional quality of students, easing the employment pressure of students, but also can relieve enterprises eager desire for directional talents. This "ground gas" Order prejob vocational education is in favor of full-time education college, which can accurately grasp the teaching content and social needs, reform and improve the professional structural and teaching model of full-time academic education, shorten the gap between theory learning and practice, so as to enhance the overall quality of college graduates in nature.

From the perspective of the development of continuing education, the sustained development of industrial economic requires a lot of "gray collar" talent objectively. "Gray collar" Talent refers to a higher level of knowledge, a strong ability to innovate, the grasp of new skills, and skilled personnel, who are high-end talents both the use of the hands and the brain. At present, China has at least tens of millions of "gray collar" talent gap, such a huge talent gap, coupled with inadequate training capacity of their own, so many companies tend to be more into the universities and launch pre-service vocational continuing Education with related institutions jointly. Continuing education should seize the opportunity to make a difference, targeted expansion of continuing education for the emerging field of social services.

\section{CONCLUSION}

College students are an important asset of society and the power source between professional innovation and progress. Whether the development of students' personal and society, it is looking forward to education through a variety of ways, to enhance the professional competence of college students, and ultimately improve the employment rate. Pre-service vocational continuing professional is the core step between college students and company achieving win-win development, which is also a key step linked college full-time education with continuing education. Employment problems are the current focus of social problems, which will require the joint efforts of the whole society to solve the employment of college students that is not an overnight thing.

\section{REFERENCES}

[1] Liu Xuanzhi. Pre-service Training of College Graduates. Technology Entrepreneurs, 2014(03): 229. (In Chinese)

[2] Liang Renchun. Employment Situation and Employment Guidance Analysis of College Students. Intelligence, 2014(08): 113. (In Chinese)

[3] Sun Pu. Reflections on the Work of College Students Employment Guidance. Higher Vocational Studies, 2012(12). (In Chinese)

[4] Qing Mei. Employment Problems of Highly Educated Graduates. Beijing: Beijing University of Technology Press, 2012, 6. (In Chinese)

[5] Zhao Tianwu, Lan Shundong. Causes and Measures Research on College Students' Difficult Employment. China College Students Employment, 2012(16): 21-22. (In Chinese)

[6] Jiang Aixian, Meng Liang, Liu Guiying. Causes and Measures Research on College Students' Difficult Employment. Education Explore, 2008 (11).(In Chinese) 